\title{
Joggyakorlat
}

\author{
KLEMENCSics AnDREA*
}

\section{Az Emberi Jogok Európai Bírósága által előidézett változások a magyar jogrendszerben}

\author{
Emberi Jogok Európai Bírósága - pilot judgment eljárás - közvetlen hatás - \\ közvetett hatás - emberi jogok nemzetközi védelme
}

Jelen tanulmány hipotézise, hogy az emberi jogok nemzeti védelmének alapjai az Európa Tanács tagállamai esetében nagymértékben a nemzetközi jogban, illetőleg az Emberi Jogok Európai Bíróságának (a továbbiakban: EJEB vagy Bíróság) ítélkezési gyakorlatában keresendőek. Az Emberi Jogok Európai Egyezménye (a továbbiakban: EJEE vagy Egyezmény) számos első generációs emberi jogot garantál, amelyet a tagállami alkotmányok lényegében azonos tartalommal épitettek be jogrendszerükbe. Az Egyezmény és a Bíróság kivételes jelentőségét az adja, hogy az EJEE és az EJEB joggyakorlata ugyan formálisan csak az alperes államra és csak az egyes konkrét ügyben kötelezőek, de a „precedens jellegü” ítélkezési gyakorlatra ${ }^{1}$, illetöleg az európai konszenzus intézményére ${ }^{2}$ tekintettel a döntések hatásai jóval tovább terjednek. ${ }^{3}$

A tanulmányban az EJEB magyar jogrendszerre kifejtett hatását vizsgálom meg részletesebben, és arra kívánok rámutatni, hogy bár az EJEB döntései nyomán a tagállamok nem kötelesek az Egyezménybe ütköző rendelkezést vagy hatóságaik által alkalmazott gyakorlatot megváltoztatni, ennek ellenére a tagállamok egyre inkább próbálják jogrendszerüket a döntéseknek megfeleltetni. Ezáltal az EJEB ítéleteinek közvetett hatása is egyre jobban érvényesül, tekintettel arra, hogy az államok

* Dr. Klemencsics Andrea migrációs szakreferens, Belügyminisztérium Határigazgatási és Nemzetközi Szerződés-előkészítő Osztály; PhD-hallgató, Pázmány Péter Katolikus Egyetem Jog- és Államtudományi Kar Nemzetközi Közjogi Tanszék, andrea.klemencsics@gmail.com.

1 Szemesı Sándor: A diszkrimináció tilalma, az Emberi Jogok Európai Bírósága gyakorlatában. CompLex, Budapest, 2009, 124.

2 Polgárı Eszter: Az európai konszenzus: elmélet és gyakorlat. Collega, 2007/2-3, 59-63.

3 PÁkozDı Csaba: A véleménynyilvánítás szabadsága és a nemzetközi jog, különös tekintettel az Emberi Jogok Európai Bíróságának joggyakorlatára. PhD-értekezés, Miskolc, 2006, 219. 
próbálják elkerülni a további elmarasztalásokat, ${ }^{4}$ amelynek következtében a Bíróság egyre inkább közös európai mércévé kezd válni. Mint ahogy azt Baka András is megállapította, az „EJEB jogi kultúrát közvetít. A bíróság esetjoga európai jogi kincs, közös érték, egy korszak fejlődését, változását tükrözi, végigkövethetök rajta a föbb jogi vonulatok. Lehet bírálni az esetjogot, hogy lassan alakul, de ebben az esetben a lassúság, az állandóság, a kiszámíthatóság is érték, mert a Bíróság egy-egy döntésével nem szaladhat elöre és nem maradhat nagyon le." ${ }^{5}$

\section{Az EJEB döntési mechanizmusa és következményei}

Amennyiben az Egyezményt valamely részes állama megsérti, akkor az összes rendelkezésre álló hazai érdemi jogorvoslati lehetőség kimerítése után fordulhat a kérelmező az EJEB-hez. Amennyiben a Bíróság a kérelmet befogadja és a kérelmező számára kedvező döntés születik, az EJEB többféleképpen szolgáltathat elégtételt: számos esetben az államot kártérítés fizetésére kötelezi, azonban, ha a jogsértés kisebb súlyú (vagy a kérelmező maga sem kér pénzbeli elégtételt), az EJEB dönthet úgy is, hogy maga a jogsértés megállapítása is kellő elégtételül szolgál. Ugyanakkor a pernyertes panaszos az eljárással kapcsolatban felmerült és igazolt költségeinek megtérítését minden esetben követelheti az államtól, természetesen csak a Bíróság által elfogadott mértékben. Fontos megjegyezni, hogy a Bíróságnak nincs hatásköre a döntés kikényszerítésére és a nemzeti bírósági ítélet megsemmisítésére, azonban a döntés sosem marad következmények nélkül. ${ }^{6}$ Erre biztosítékot az Európa Tanács Miniszteri Bizottsága jelent, amely az EJEB-döntés végrehajtásának felügyeletét végzi. A Miniszteri Bizottság hat hónapon belül napirendjére túzi minden ítélet végrehajtásának az ellenőrzését, és mindegyikröl rendszeres beszámolót kér a tagállamoktól. Ha az államok nem teljesítik az ítéletekből származó kötelezettségeiket, annak elsősorban diplomáciai és viszonylag szük körü jogi, illetve nemzetközi jogi szankciói vannak.

Azonban az EJEB-döntésnek az adott ország jogrendszerére közvetlen vagy közvetett hatása is lehet. Közvetlenül hat a döntés, amennyiben annak következményeként jogszabály vagy jogszabály bevett értelmezésének megváltoztatására kerül sor. Ezzel szemben közvetett hatásnak minősül, amennyiben a tagállami alkotmánybíróság vagy a bíróságok gyakorlatában jelenik meg az EJEB döntése, és ezen keresztül gyakorol tényleges hatást a jogrendszerre. ${ }^{7}$

A továbbiakban a konkrét esetek kapcsán azt vizsgálom, hogy az EJEB döntései milyen közvetlen, illetöleg közvetett hatást idéztek elö a magyar jogrendszerben. A vizsgálat tárgyává kizárólag a 2014-ben hozott EJEB- és magyar alkotmánybírósági döntéseket teszem, azon okból kifolyólag, hogy ezen legfrissebb határozatok is

4 PÁkozdi: i. m., 201-202.

5 BAKA András: Irányt mutatunk, de nem avatkozunk be durván a nemzeti jogokba. Fundamentum, 2000/4, 39.

6 Koltay András: A szólásszabadság alapvonalai - magyar, angol, amerikai és európai összehasonlításban. Századvég, Budapest, 2009, 107.

7 Koltay: i. m., 113-114. 
kivétel nélkül egy 5-10 éves vitatott magyar szabályozásra való, pozitív vagy negatív irányba történő hazai jogalkotási reakciót mutatnak be, és alkalmasak lehetnek kellő következtetések levonására.

\section{Jogszabály-módosulást elöidézö, ún. közvetlen hatások}

\subsection{Gajcsi kontra Magyarország ügy}

Az EJEB 2014. szeptember 24. napján hozott döntést Gajcsi László ügyében, melynek előzménye egy 2006-os, a magyar államot ugyancsak elmarasztaló ítélet ${ }^{9}$ volt, és melyben a kérelmező jogellenesen történő pszichiátriai intézetben való fogvatartását az EJEE 5. cikkével, azaz a szabadsághoz és biztonsághoz való joggal ellentétesnek ítélte meg a Bíróság. A strasbourgi döntés után a Kaposvári Bíróság 2008-ban visszaállította a kérelmező cselekvőképességét, azonban választójogát nem, amelynek eredményeként a 2010. április 11-én tartott országgyülési választásokon nem tudott részt venni.

Az EJEB a Kiss Alajos kontra Magyarország ${ }^{10}$ ügyet alapul véve döntött a kérelmező ügyében. A hivatkozott döntésben Kiss Alajost mániás depresszió miatt cselekvőképességet korlátozó gondnokság alá helyezték, amelynek következtében az Alkotmány 70 . $\S(5)$ bekezdése alapján automatikusan elvesztette választójogát. $A z$ EJEB döntésében kifejtette, hogy a magyar szabályozás nem tesz különbséget a cselekvőképességet kizáró és korlátozó gondnokság között, ezzel pedig a gondnokság alatt állóknak a választójogtól való mérlegelés nélküli megfosztása a választójogosult magyar népesség $0,75 \%$-át érinti. ${ }^{11}$

A döntés nyomán a jogalkotónak két lehetősége állt fent, hogy létrehozza az Egyezménnyel összhangban levő szabályozást: az első - és liberálisabb - megoldás szerint a gondnokság alatt állók automatikusan rendelkezhetnének választójoggal. A másik megoldás alapján a cselekvőképességet korlátozó gondnokság alatt állók választójoga minden esetben egyedi bírói mérlegelés tárgyát képezhetné. ${ }^{12}$

Az Alaptörvény megalkotása során a magyar szabályozás reagált az EJEB döntésére, és az Alkotmány vitatott rendelkezését az alábbiak szerint változtatta meg: „Nem rendelkezik választójoggal az, akit büncselekmény elkövetése vagy belátá-

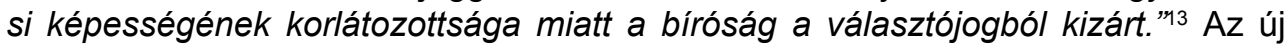
magyar szabályozás a cselekvőképesség fogalmát felváltotta a belátási képesség fogalmával, emellett eltörölte a választójog automatizált elvesztését és azt - a második lehetőséget választva - egyedi bírói döntés függvényévé tette, amivel egy-

Gajcsi kontra Magyarország ügy, 2014. szeptember 23-i ítélet (ügyszám: 92924/10).

Gajcsi kontra Magyarország ügy, 2006. október 3-i ítélet (ügyszám: 34503/03).

10 Kiss Alajos kontra Magyarország ügy, 2010. május 20-i ítélet (ügyszám: 38832/06).

Kiss Alajos kontra Magyarország ügy, 2010. május 20-i ítélet (ügyszám: 38832/06), 39. pont.

BodnÁR Eszter: A Kiss Alajos ügy. Jogesetek Magyarázata, 2011/1, 70-71.

13 Alaptörvény, XXIII. cikk (6) bekezdés. 
ben egy régóta tartó vita végére is pontot tett. ${ }^{14}$ Azonban említést érdemel, hogy a jelenlegi szabályozás sem kompatibilis az Európa Tanács Miniszteri Bizottságának $\mathrm{CM} / \operatorname{Rec}(2011) 14^{15}$, 2011. november 16. napján közzétett ajánlásával, valamint a Joggal a Demokráciáért Európai Bizottság (ismertebb nevén: Velencei Bizottság) állásfoglalásával, tekintettel arra, hogy mindkét fentebb hivatkozott dokumentum javasolja ${ }^{16}$ az államoknak a korlátozott cselekvőképességgel rendelkező fogyatékos állampolgárok választójogára vonatkozó mindenféle korlátozás eltörlését. Ezenkívül az ENSZ Fogyatékossággal Élő Személyek Jogainak Bizottsága (CRP) is több ízben felhívta Magyarországot ${ }^{17}$ az Alaptörvény rendelkezéseinek megváltoztatására, tekintettel arra, hogy a jelenlegi szabályozás diszkriminatív a fogyatékos személyekkel szemben. Így az EJEB által kívánt átültetés - ami a fentiek szerint nem strasbourgi sajátosság, hanem a nemzetközi jog általános gyakorlatával is azonos - nem valósult meg, azonban az eddigi szabályozáshoz képest mindenképpen elörelépést jelent.

\subsection{Vajnai kontra Magyarország ${ }^{18}$, Vajnai és Horváth kontra Magyarország ${ }^{19}$ és Noé, Vajnai és Bakó kontra Magyarország ${ }^{20}$ ügyek}

A döntések előzményét egy 2003 februárjában történt esemény szolgáltatta, amikor Vajnai Attila, a Munkáspárt akkori alelnöke Budapesten, a rendszerváltás során eltávolított Marx és Engels szobornál tartott beszéde során $5 \mathrm{~cm}$ széles, ötágú vörös csillagot viselt. A jelen lévő rendőr felszólítására a csillagot zakójáról eltávolította, azonban a Pesti Központi Kerületi Bíróság előtt eljárás indult ellene, amelynek eredményeként egy év felfüggesztett szabadságvesztés büntetésre ítélték. A fellebbezést követően a Fővárosi Bíróság (mai Fővárosi Törvényszék) előzetes döntéshozatal iránti kérelmével az Európai Unió Bíróságához fordult ${ }^{21}$, tekintettel arra, hogy számos, Magyarországon tiltott jelkép, így a vörös csillag is, más uniós országokban nem tartoznak tiltás hatálya alá. Az Európai Unió Bírósága azonban az előzetes döntéshozatal iránti kérelmet elutasította, tekintettel arra, hogy az ügy eldöntése nem tartozik hatáskörébe.

14 GuRBAI Sándor: A gondnokság alá helyezett személyek választójogának vizsgálata az Emberi Jogok Európai Bíróságának a Kiss v. Magyarország ügyben meghozott ítélete alapján. Közjogi Szemle, 2010/4, 31-44.

15 Recommendation $\mathrm{CM} / \operatorname{Rec}(2011) 14$ of the Committee of Ministers to Member States on the Participation of Persons with Disabilities in Political and Public Life, Appendix.

16 European Commission for Democracy Through Law (Venice Commission): Revised Interpretative Declaration to the Code of Good Practice in Electoral Matters on the Participation of People with Disabilities in Elections. Study No. 584/2010. A Velencei Bizottság tanulmányában kifejti, hogy az európai választójog alapvető elve az egyetemes választójog, és ebben a vonatkozásban pedig a fogyatékossággal élő embereket nem érheti hátrányos megkülönböztetés. Ezzel a megállapítással a Velencei Bizottság is egyértelművé teszi, hogy nem tartja elfogadhatónak a gondnokság alá helyezett állampolgárok választójogának korlátozását.

17 Committee on the Rights of Persons with Disabilities, Communication No. 4/2011, View of 9 September 2013.

18 Vajnai kontra Magyarország No. 4. ügy, 2014. szeptember 23-i ítélet (ügyszám: 6061/10).

19 Horváth és Vajnai kontra Magyarország ügy, 2014. szeptember 23-i ítélet (ügyszám: 55795/11, 55798/11).

20 Noé, Vajnai és Bakó kontra Magyarország ügy, 2014. szeptember 23-i ítélet (ügyszám: 24515/09, 24539/09, 24611/09).

21 C-328/04. sz., Vajnai Attila elleni büntetöeljárás ügy, 2005. október 6-i végzés (ECLI:EU:C:2005:596). 
Vajnai ezután fordult az EJEB-hez, amely döntésében megállapította, hogy bár a kiszabott szankció a magyar jog által előirt volt, azonban a szólásszabadság és különösen a politikai véleménynyilvánítás alapvető fontosságú a demokratikus társadalmi berendezkedés müködése szempontjából. A Bíróság továbbá azt is kifejtette, hogy a vörös csillag több jelentéssel bír, és több országban még ma is a Munkáspárt jelképe (Lettország, Szlovákia).

A 2014. évi döntés alapjául szolgáló kérelmek hasonló tényálláson alapultak. ${ }^{22}$ Első esetben a kérelmet Vajnai Attila nyújtotta be, arra hivatkozással, hogy 2009. május 18. napján békés demonstráción vett részt, amely során kabátján ötágú vörös csillagot viselt. A rendezvényen jelen lévő rendőr felszólította a jelkép eltávolítására, amelyet el is koboztak. A kérelmező sérelmezte a rendőri intézkedést, ezért a Fővárosi Bírósághoz (mai Fővárosi Törvényszékhez) fordult, amely a kérelmet elutasította az eljárás időpontjában hatályos 1978. évi IV. törvénnyel kihirdetett Büntető Törvénykönyv (Btk.) 269/B. szakasza alapján. A fellebbezést követően a Legfelsőbb Bíróság (Kúria) az elsőfokú döntést helybenhagyta, a már említett, 2008-as strasbourgi bírósági döntés ellenére, melyet a kormány később azzal indokolt, hogy a két ügy különböző, mivel a Btk. szerint továbbra is tilos a vörös csillag viselése, mely azonban az utóbbi esetben csupán eltávolításra került, egyéb intézkedést nem foganatosítottak Vajnai Attilával szemben.

A második esetben, a Horváth és Vajnai ügyben a kérelmezőket elítélték 2003 és 2005 között megvalósított büncselekmény miatt. Vajnai esetében ez vörös csillag viselését (rendezvényen, televízióban, bíróságon, ügyészségen), míg Horváth esetében sarló és kalapács jelkép viselését jelentette nyilvános rendezvények alkalmával. Vajnait 120 ezer forint pénzbüntetésre és 45 ezer forint eljárási költség megfizetésére ítélték, míg Horváthot egy év próbaidőre felfüggesztették.

A harmadik ügyben, a Noé, Vajnai és Horváth kontra Magyarország ügyben a kérelmezőket elmarasztalta a magyar bíróság, tekintettel arra, hogy antikapitalista mikulás nevű tiltakozó rendezvényükön, zászlójukon és szórólapjaikon vörös csillagot használtak. A rendezvény célja az volt, hogy a fogyasztók figyelmét felhívja a szegénységre és a piacgazdaság hátrányaira. A jelen lévő rendőr azonban a rendezvény beszüntetésére kötelezte őket, majd a IV. kerületi rendőrkapitányságra előállították és ott kihallgatták őket.

Az EJEB által vitatott magyar gyakorlatok kivétel nélkül az akkor hatályos Btk. rendelkezésein alapultak. Mialatt zajlott az EJEB előtti eljárás, az Alkotmánybíróság 4/2013. (II. 21.) számú határozatában kimondta, hogy a Büntető Törvénykönyvröl szóló 1978. évi IV. törvény 269/B. §-a Alaptörvény-ellenes, ezért 2013. április 30-ával

22 Ugyancsak említést érdemel a Fratanoló kontra Magyarország ügyben 2011. november 3-án meghozott ítélet (ügyszám: 29459/10), melyben az EJEB ugyancsak elmarasztalta Magyarországot. Az Országgyülés azonban az 58/2012. (VII. 10.) OGY határozatban elvi éllel mondta ki, hogy a marasztaló ítélettel nem ért egyet, tekintettel Magyarország történelmi múltjára és alkotmányos berendezkedésére amellyel megfelelő módon került megalkotásra a magyar büntető törvénykönyvben szereplő tényállás. Az Országgyűlés ezen túlmenően azt is rögzítette, hogy a tényállás alkalmazása miatt meghozott vagy esetlegesen meghozandó ítéletek alapján az államot terhelő fizetési kötelezettség összegével a pártok központi költségvetési támogatásának a csökkentését tartja szükségesnek, mellyel egyértelmüen kifejezte, hogy a Btk. módosítását semmilyen körülmények között nem tartja sem szükségesnek, sem indokolhatónak. 
megsemmisítette, amit az új Btk. vonatkozó rendelkezéseire is kiterjesztett. ${ }^{23} \mathrm{Az} \mathrm{Al}-$ kotmánybíróság indoklásában kifejtette ${ }^{24}$ hogy a jelenlegi szabályozás nem kellően világos és körülhatárolt, mivel a jelképhasználatot általában rendeli büntetni, jóllehet a célzatnak, az elkövetés módjának vagy a kiváltott eredménynek figyelembevétele, valamint az egyes szimbólumok esetében azok használatának módja és célja elengedhetetlen lehet. ${ }^{25}$ A 2012. C. törvény (új Btk.) 335. §-a az önkényuralmi jelképek használatáról már ennek megfelelően rögzíti, hogy abban az esetben valósul meg a büncselekmény, ha az illető a jelképeket a köznyugalom megzavarására alkalmas - különösen az önkényuralmi rendszerek áldozatainak emberi méltóságát vagy kegyeleti jogát sértő - módon terjeszti, használja vagy közszemlére teszi. Az EJEB marasztaló ítéletének központi érve a jelképek többértelmüsége volt, amely azonban Magyarország esetében nem feltétlenül igaz. ${ }^{26}$ Így az alkotmánybírósági határozat igazi elméleti problémája az volt, hogy az Alkotmánybíróság továbbra is kövesse a saját korábbi határozatában lefektetett megközelítést, ${ }^{27}$ melyet a Fratanoló és Vajnai ügy vizsgálata során az EJEB az Emberi Jogok Európai Egyezményével ellentétesnek minősített. ${ }^{28} \mathrm{~A}$ strasbourgi esetek, bár nem válnak pro forma a belső jog részévé, ${ }^{29}$ azonban a 61/2011. (VII. 13.) AB határozat kimondta, hogy a pacta sunt servanda elve alapján az Alkotmánybíróságnak követnie kell a strasbourgi gyakorlatot, akkor is, ha ez a határozatokból közvetlenül nem következne..$^{30}$ Így az EJEB a saját korábbi határozatához ragaszkodva gyakorlatilag kikényszerítette a magyar szabályozás megváltoztatását, amely az Egyezménynek való megfelelés érdekében az önkényuralmi rendszerek áldozatainak emberi méltóságát sértő fordulattal áthidalta az EJEB által megkövetelt véleménynyilvánítás szabadságának korlátok nélküliségét a többértelmű jelképek esetén. Így az EJEB által sérelmezett rendelkezést, vagyis az önkényuralmi jelképek mindenféle nyilvános ábrázolásának általános jelleggel történő büntetését megszüntette. Az ügy érdekessége, hogy nem csupán közvetlen, hanem (a késöbbiekben tárgyalandó) közvetett hatása is volt az EJEB döntésének.

23 4/2013. (II. 21.) $\mathrm{AB}$ határozat, $\mathrm{ABH}$ 2013, 128, különösen a 48-50. pontok. Az Alkotmánybíróság rámutat az EJEB azon érvelésére, amely a korábbi alkotmánybírósági gyakorlat változását idézte elő: eszerint a szimbólumnak többes jelentése van, amelyek részletes vizsgálata esetén lehet csak megállapítani, hogy mely jelentéssel összefüggő kijelentések tartoznak az Egyezmény 10. cikkének védelme alá, amelyek még tolerálhatók egy demokratikus társadalomban.

24 KovÁcs Péter: International Law in the Recent Jurisprudence of the Hungarian Constitutional Court: Opening of a New Tendency? In: Seibert-Fohr, Anja-Villiger, Mark. E.: Judgments of the European Court of Human Rights - Effets and Implementation. Ashgate, 2015, 261-262.

25 4/2013 (II. 21.) AB határozat, $A B H$ 2013, 128, 62. pont.

26 Koltay András: A Vajnai ügy. Az Emberi Jogok Európai Bíróságának ítélete a vörös csillag viselésének büntethetőségéröl. Jogesetek Magyarázata, 2010/1, 74.

27 A 14/2000. (V. 12.) AB határozattal az Alkotmánybíróság a 269/B. § alkotmányellenességének megállapítását és megsemmisítésére beadott indítványokat elutasította. $\mathrm{ABH} 2000,83$.

28 KovÁcs Péter: Az Emberi Jogok Európai Bírósága ítéletére való hivatkozás újabb formulái és technikái a magyar Alkotmánybíróság, valamint néhány más európai alkotmánybíróság mai gyakorlatában. Alkotmánybírósági Szemle, 2013/2, 77.

29 MolnÁR Tamás: A nemzetközi jogi eredetü normák beépülése a magyar jogrendszerbe. Dialóg-Campus, Budapest-Pécs, 2013, 182-184.

30 14/2000. (V. 12.) AB határozat, $A B H 2000,83$. 


\subsection{Karácsony és mások kontra Magyarország ügy ${ }^{31}$}

A Vajnai-ügyhöz hasonlóan, jelen esetben is a kérelmezők véleménynyilvánítási szabadságuk korlátozását sérelmezték. Az ügy kérelmezői a magyar parlament egyik ellenzéki pártjának (Lehet Más a Politika) tagjai, akik molinók felmutatásával fejezték ki véleményüket az információs önrendelkezési jogról és az információszabadságról szóló törvény - véleményük szerint rendkívüli gyorsasággal, megfelelő vizsgálat nélkül történő - elfogadása, valamint a trafiktörvény és földtörvény módosítása során. A házelnök az Országgyülés munkájának megzavarása miatt 170 euró és 600 euró közötti pénzbírsággal sújtotta a kérelmezőket, tekintettel arra, hogy cselekményükkel megzavarták az Országgyülés munkáját.

A kérelmezők szerint a bírság kiszabása sértette az Egyezmény 10. cikke által biztosított véleménynyilvánítás szabadságát, a 13. cikk szerinti hatékony jogorvoslathoz való jogot és a 14. cikk szerinti diszkrimináció tilalmát, föként, hogy a bírság kizárólag a házelnök hatáskörében lett kiszabva. Habár az ügy kapcsán az Alkotmánybíróság a 3206/2013. (XI. 18.) és a 3207/2013. (XI. 18.) számú határozatában az Országgyülésröl szóló 2012. évi XXXVI. törvény (a továbbiakban: Ogytv.) vitatott rendelkezéseivel szembeni kifogást elutasította, ${ }^{32}$ azonban említést érdemel, hogy Paczolay Péter, az Alkotmánybíróság akkori elnöke határozathoz csatolt különvéleményében a magyar szabályozás ugyanazon hiányosságaira mutat rá, mint a döntésében az EJEB.

Az eljárás során az EJEB a hazai jogszabályok közül vizsgálata alá vonta az Alaptörvényt, az Ogytv.-t, továbbá az Európa Tanács Parlamenti Közgyülésének, illetöleg az Európai Parlamentnek az eljárási szabályzatát. Az Európai Parlament eljárási szabályzatánál külön kiemelte, hogy a képviselők magatartását a kölcsönös tiszteletnek kell jellemeznie, és tiszteletben kell tartaniuk a Parlament méltóságát, amely magába foglalja, hogy nem tanúsíthatnak olyan magatartást, amely a Parlament munkáját sérti vagy akadályozza. ${ }^{33} \mathrm{~A}$ Bíróság megállapította, hogy a fentiek alapján bevett gyakorlat, hogy a parlamentek szankciókat alkalmaznak a szabályzatukat megsértő képviselőkkel szemben. Ennek magyarázata, hogy amíg a mentelmi jog intézménye a külső behatások ellen védi a parlament és tagjainak tekintélyét, addig az ily módon kiszabott szankciók a belső jogsértések ellen nyújtanak védelmet. ${ }^{34}$

31 Karácsony és mások kontra Magyarország ügy (ügyszám: 42461/13. és 44357/13.) Az ügyben a Nagykamara ítélete a tanulmány kéziratának lezárásáig (2015. szeptember 30.) nem került meghozatalra.

32 „25] A képviselői szólásszabadság tekintetében az Alkotmánybíróság szerint különbséget kell tenni a véleménynyilvánítás szabadsága és a véleménynyilvánítás megjelenítésének formája, módja között. $A$ véleménynyilvánítás szabadsága - alkotmányos alapjogként - fokozott védelmet élvez, azt csak az emberi méltósághoz, a becsülethez és a jó hírnévhez való jogok védelme, valamint a magyar nemzet, a nemzeti, etnikai, faji vagy vallási közösségek méltósága - mint külső korlátok - korlátozhatják. Más a helyzet azonban a vélemény külső megjelenítésének formájával, módjával kapcsolatban. Erre nézve ugyanis az Országgyülésnek jogában áll olyan (ön)korlátozó rendelkezéseket alkotni, amelyek garantálhatják a testület méltóságát és zavartalan müködését. Ezek a szabályok gyakorlatilag olyan »türési határt“ vonnak meg, amelyen belül maradva még biztositható az érdemi testületi müködés."

33 Európai Parlament Eljárási Szabályzat, különösen a 165-166. cikkek.

34 Karácsony és mások kontra Magyarország ügy, 2014. szeptember 16-i ítélet (ügyszám: 42461/13), 18. és 44. pontok. 
A Bíróság figyelembe vette a 10. cikk rendelkezését, majd az elérendő célt és úgy vélte, hogy bizonyos körülmények között lehetőség van a véleménynyilvánítás szabadságának ilyen jellegü korlátozására, azonban jelen beavatkozás nem tekinthetö „szükségesnek egy demokratikus társadalomban” a 10. cikk (2) bekezdésére tekintettel, mivel az Országgyülés elnöke enyhébb szankciókat nem alkalmazott (megrovás, figyelmeztetés). ${ }^{35} \mathrm{~A}$ Bíróság döntése értelmében így a kérelem a 10. cikk és 13. cikk tekintetében elfogadható, míg a többi rész tekintetében a kérelmet a Bíróság elfogadhatatlannak nyilvánította. Az EJEB így két ok miatt marasztalta el Magyarországot, egyrészt a megfelelő jogorvoslat hiánya, másrészt a fokozatosság hiánya, azaz egyből a legsúlyosabb büntetés alkalmazása miatt.

Az Ogytv. számos rendelkezését az Országgyülés már az EJEB döntésének megszületése előtt módosította a 2014. évi XIV. törvénnyel. A módosítás többek között hatályon kívül helyezte a 49. § (7)-(8) bekezdését, az 50. § (2a) bekezdését, illetöleg az 52. $\S(5)$ bekezdését, amely szerint a házelnök a magatartás tanúsításától számított öt napon belül jogosult a képviselö adott havi tiszteletdíjának csökkentésére, illetőleg képviselői jogai gyakorlásának felfüggesztésére javaslatot tenni. Továbbá beiktatásra került a 38/A. §, amely szerint tárgyi, képi vagy hanghordozó útján történő szemléltetés kizárólag a Házbizottság engedélyével lehetséges.

Ez a módosítás azonban nincs összhangban az EJEB ítéletében megfogalmazott követelményekkel. Amint arra az Alkotmánybíróság 3206/2013. (XI. 18.) számú határozatához csatolt különvéleményében Paczolay Péter is rámutatott, jelen szabályozásból hiányzik a szankciók lépcsőzetessége ${ }^{36}$ és álláspontja szerint emiatt az Ogytv. 52. § (2) bekezdés a) pontjának Alaptörvény-ellenességét kellett volna megállapítani azokban az esetekben, amelyekben a jogkövetkezmények alkalmazására a kifogásolható tartalmú megszólalást követően, de rendreutasítás és figyelmeztetés nélkül került sor ${ }^{37} \mathrm{Az}$ EJEB határozatában ${ }^{38}$ a véleménynyilvánítás szabadsága megsértésének indokaként a Paczolay különvéleményében megállapított okokat hozza fel, melyre a jogszabály-módosítás továbbra sem ad megfelelő biztosítékokat. Paczolay a különvéleményében kihangsúlyozta, hogy jelen ügyben nincsen a véleményszabadsággal versengő másik alapjog, ezért az állami fellépés lehetőségének korlátozottnak kell lennie. ${ }^{39}$ Ezen megállapitás fényében a 38/A. $\S$ beiktatása az EJEB ítéletének szemszögéből nézve egyenesen a jogszabály kívánttal ellentétes irányba történő módosítását jelenti.

\section{A joggyakorlatra gyakorolt, ún. közvetett hatás}

Az EJEB-nek a magyar jogrendszerre gyakorolt közvetett hatása értelemszerüen kisebb mértékü, mint a közvetlen hatása. A közvetett hatás vizsgálatánál azonban célszerủ szétválasztani az Alkotmánybíróságra, illetőleg az egyéb bírói fórumokra gyakorolt hatást.

35 Karácsony és mások kontra Magyarország ügy, 2014. szeptember 16-i ítélet (ügyszám: 42461/13), 88. pont.

36 3206/2013. (XI. 18.) AB határozat, ABH 2013, 2395, 92. pont.

37 3206/2013. (XI. 18.) AB határozat, ABH 2013, 2395, 117. pont.

38 Karácsony és mások kontra Magyarország ügy, 2014. szeptember 16-i ítélet (ügyszám: 42461/13), 88. pont.

39 3206/2013. (XI. 18.) AB határozat, ABH 2013, 2395, 105. pont. 
Az Alkotmánybíróság legelöször a 23/1990. (X. 31.) számú, a halálbüntetés eltörléséről szóló határozatában hivatkozott ${ }^{40}$ az EJEE-re. Az azóta tartó tendencia szerint az Alkotmánybíróság az összes döntésének mintegy 9-10 százalékában hivatkozott az Egyezményre és az EJEB gyakorlatára. Pontos számot azonban nehezen lehet megadni, tekintettel a váltakozó, illetőleg fel nem tüntetett hivatkozásokra. ${ }^{41}$ Szalai Anikó statisztikája szerint a 2011. évvel bezárólag az összes alkotmánybírósági döntés vizsgálata azt mutatja, hogy 117 alkalommal történt az $A B$ határozatok indoklásában kifejezett utalás az EJEE-re, míg további 36 alkalommal a különvélemények utaltak az Egyezményre vagy az EJEB gyakorlatára. ${ }^{42}$

Négyféle hivatkozásfajtát tudunk az Alkotmánybíróság gyakorlatában megkülönböztetni: első az összefoglaló hivatkozás ${ }^{43}$, amely konkrét aktus említése nélkül általában hivatkozik nemzetközi kötelezettségre, és benne az EJEB joggyakorlatára. Második a konstruktív ér $v^{44}$, amely az értelmezést egyedül, másik érv mellett alkotja, ennél gyengébb a kiegészítö konstruktív érv, amely másodlagosan több más érv mellett tölti be az alakító érv szerepét. Az utolsó az igazoló ér ${ }^{45}$, amely a kialakított értelmezést elősegíti-alátámasztja, azonban nem látszik kifejezetten a szerepe az érvelésben ${ }^{46} \mathrm{Az}$ Alkotmánybíróság gyakorlatában mind a négy típus megtalálható, de leginkább a konstruktív és igazoló érvek kapnak szerepet. Természetesen ezek során a leggyakrabban hivatkozott cikkek az EJEE 6. és 10. cikkei a vonatkozó joggyakorlattal együtt. ${ }^{47}$ A 6. cikk esetében ez nem meglepő, tekintettel arra, hogy Magyarország elmarasztalásainak legnagyobb részét a tisztességes eljáráshoz való jog valamely aspektusának sérelme teszi ki (az EJEB hivatalos statisztikái szerint 2014. december 31-ig összesen 267 alkalommal került sor a magyar állam elmarasztalására a 6 . cikk sérelme miatt).

Az EJEE 10. cikkére is többször hivatkozik az Alkotmánybíróság, melyben a fent említett 4/2013. (II. 21.) számú határozat hozott a legnagyobb változást, amikor is az Alkotmánybíróság a saját korábbi döntését megváltoztatva az EJEB megközelítését fogadta el, és megállapította a Büntető Törvénykönyv Alaptörvény-ellenességét. Azonban az EJEE egyéb cikkei is rendszeres hivatkozásul szolgálnak az Alkotmánybíróság döntéseiben. ${ }^{48} \mathrm{~A}$ legutóbbi, legnagyobb horderejü ügyek között a börtönök túlzsúfoltságával kapcsolatos III/1292/2014. AB határozat és a tényleges életfogytig tartó szabadságvesztéssel kapcsolatos III/00833/2014. AB végzés szerepel, melyekben kivétel nélkül részletesen hivatkoznak az EJEB joggyakorlatára.

40 23/1990. (X. 31.) AB határozat, $A B H$ 1990, 88, 4. pont.

41 SzalAi Anikó: Az Emberi Jogok Európai Bírósága ítélkezésének megjelenése a magyar Alkotmánybíróság gyakorlatában. Kül-Világ, 2010/4, 15.

42 Blutman László-Csatlós Erzsébet-Schiffner Imola: A nemzetközi jog hatása a magyar joggyakorlatra. HVG-ORAC, Budapest, 2014, 408.

43 36/2000. (X. 27.) AB határozat, $A B H$ 2000, 241 és 34/1994. (VI. 24.) AB határozat, $A B H$ 1994, 177.

44 34/2004. (IX. 28.) AB határozat, ABH 2004, 490.

45 47/2009. (IV. 21.) AB határozat, $A B H 2009,341$.

46 Blutman-Csatlós-Schiffner: i. m., 435-437.

47 Blutman-Csatlós-Schiffner: i. m., 409.

48 A leggyakrabban a 8. (magán- és családi élethez való jog), 5. (szabadsághoz és biztonsághoz való jog) és 2. cikk (élethez való jog) képezi a hivatkozás tárgyát a fent említett cikkeket követően. 
A börtönök túlzsúfoltságával kapcsolatos III/1292/2014. AB határozat, melyet az Alkotmánybíróság a magyarországi fegyintézetek celláinak méretével kapcsolatban hozott, több szempontból is nagy érdeklődésre tarthatott számot. Az alapügyben három kártérítés iránti pert indítottak a Fővárosi Törvényszéken, melyben az eljáró bíró az ellentmondó szabályozás miatt alkotmánybírósági eljárást kezdeményezett. ${ }^{49} \mathrm{Az}$ Alkotmánybíróság határozatában megállapította, hogy a szabadságvesztés és az előzetes letartóztatás végrehajtásának szabályairól szóló 6/1996. (VII. 12.) IM rendelet 137. $\S(1)$ bekezdése Alaptörvény-ellenes és az EJEE 3. cikkével, a kínzás, az embertelen vagy megalázó bánásmód tilalmával és az erre vonatkozó EJEB-joggyakorlattal is ellentétes, ${ }^{50}$ mivel nem biztosítja a minimális $4 \mathrm{~m}^{2}$ mozgásteret a fogvatartottak számára, ezért 2015. március 31-i hatállyal megsemmisítette a szóban forgó rendeletet. A jogalkotó azonban nem várta meg a határidőt, és a rendeletet 2015. január 1-jével hatályon kívül helyezte, azonban a sérelmezett $3 \mathrm{~m}^{2}$ rendelkezést a 16/2014. (XII. 19.) IM rendelet 121. § (1) bekezdése a korábbival azonos tartalommal vette át, így az Egyezmény-ellenes állapot véleményem szerint továbbra is fennáll.

Ezt követően az EJEB 2015. március 10. napján ${ }^{51}$ elmarasztalta Magyarországot az EJEE 3. cikkének (kínzás, embertelen vagy megalázó bánásmód tilalma) megsértése miatt. Az elmarasztalás alapjául szolgált számos nemzetközi dokumentum, mint például a Foglyokkal való Bánásmód Általánosan Elfogadott Minimális Szabályai (1955), az Európa Tanács Kínzás Elleni Bizottsága (CPT) általános jelentéseinek kivonatai, illetöleg a 2013 áprilisában Magyarországról készített CPT-jelentés. Ez utóbbi jelentésében a CPT kihangsúlyozta a magyar börtönökben uralkodó túlzsúfoltság elleni cselekvés azonnali szükségességét, melyet az EJEB is megállapított a Szél-ügyben. ${ }^{52} \mathrm{~A}$ Szél-ügyben a strasbourgi bíróság kártérítést ítélt meg a kérelmező számára, melyet követően számos hasonló ügyben döntött hasonló módon a Bíróság, nyilvánvalóvá téve a strasbourgi ítélkezési gyakorlat következetességét, ${ }^{53}$ amely azonban, miként arra Szemesi Sándor is rámutat, korántsem mechanikus, pusztán az elítélt számára rendelkezésre álló férőhelyet vizsgáló, hanem a stras-

49 Az első kérelmező Baracskán egy $30 \mathrm{~m}^{2}$ alapterületủ cellában töltötte büntetését 16 másik társával együtt, így csupán $1,76 \mathrm{~m}^{2}$ mozgástér jutott egy före. A második kérelmező a Jász-Nagykun-Szolnok Megyei Büntetés-végrehajtási Intézet körülményeit sérelmezte. Elmondása szerint a $9 \mathrm{~m}^{2}$-es, szellözés nélküli, a lakótértöl mindössze egy függönnyel elválasztott WC-s cellán négyen osztoztak, amely alapján $2,25 \mathrm{~m}^{2}$ jutott egy-egy rabra. A harmadik kérelmező, Tóth Gábor három büntetés-végrehajtási intézet körülményeit is kifogásolta: elsőként a Hajdú-Bihar Megyei Büntetés-végrehajtási Intézetben előzetes letartóztatása idején négyen osztoztak egy $10 \mathrm{~m}^{2}$ alapterületủ cellán, így csak $2,5 \mathrm{~m}^{2}$ jutott minden egyes fogvatartottnak. A másik két büntetés-végrehajtási intézetben hasonló körülmények mellett éltek a rabok, azonban ott még a WC és a cella megfelelő elszeparálása sem történt meg. Pesti Lászlóra Márianosztrán $2,86 \mathrm{~m}^{2}$, Fakó Attilára a pálhalmai börtönben $1,5 \mathrm{~m}^{2}$ és $2,2 \mathrm{~m}^{2}$ közötti tér, míg Kapczár Gáborra a szegedi fegyház és börtönben $2,67 \mathrm{~m}^{2}$ jutott.

50 III/1292/2014. (X. 28.) AB határozat, ABH 2014, 916, 3. pont.

51 Varga és mások kontra Magyarország ügy, 2015. március 10-i ítélet (ügyszám: 14097/12, 45135/12, 73712/12, 34001/13, 44055/13, 64586/13).

52 Szél kontra Magyarország ügy, 2011. június 7-i ítélet (ügyszám: 30221/06).

53 BECÁNICS Adrienn: Az elítéltekkel való bánásmód kérdései az Emberi Jogok Európai Bírósága gyakorlatában, különös tekintettel a magyar vonatkozású ügyekre. Jogtudományi Közlöny, 2013/9, 416. 
bourgi bíróság ítéleteinek meghozatala során az egyéb fegyintézeti körülményeket is értékeli. ${ }^{54}$

Az EJEB 2015. március 10-i ítéletének súlyát jelzi, hogy jelen döntést az EJEB ún. pilot-eljárás keretében bírálta el. ${ }^{55}$ Ezt az eljárási formát a strasbourgi bíróság fejlesztette ki, az egyre nagyobb ügyhátralék csökkentése, ezek közül is elsősorban az ún. ismétlődő ügyek (repetitive cases) gyorsabb megoldása érdekében. Az új eljárásrend lényege, hogy a nemzeti jogoknak az Egyezménnyel ellentétes müködését, azaz rendszerproblémáit képes orvosolni azáltal, hogy nem minden esetet vizsgál meg külön-külön, hanem az adott problémás ügycsoportok közül kiválaszt egyet vagy néhányat, és az eljárás lefolytatása alatt felfüggeszti vagy elhalasztja a többi hasonló ügy elbírálását. A Bíróság határozatában felhívja az érintett kormányt az Egyezmény rendelkezéseit sértő gyakorlatának beszüntetésére, és meghatározza a nemzeti törvények Egyezményhez való igazításához szükséges lépéseket. A Bíróság így először az adott tagállamot hívja fel a tömeges jogsértés megszüntetésére, és csak ennek hiányában kezdi meg a többi ügy vizsgálatát. Az eljárásnak több gyenge pontja van, többek között a tömeges jogsértések közül az esetek kiválasztásának véletlenszerüsége, illetőleg az Egyezmény-ellenes szabályozás megállapítását követően az adott kormány együttmüködési hajlandóságának hiánya a nemzeti szabályozás megváltoztatására. ${ }^{56}$

Ezen ügy érdekességét adja, hogy az EJEB nem Magyarország esetében élt elöször a piloteljárással a börtönök túlzsúfoltsága miatt, ugyanis a Torreggiani-ügyben ${ }^{57}$ Olaszországot is ugyanezen eljárás keretében marasztalta el az olasz börtönök túlzsúfoltsága miatt, mely a strasbourgi bíróság szerint ugyancsak egy strukturális jellegü probléma eredménye. ${ }^{58}$

A többi hazai bírói fórum határozatait áttekintve azt láthatjuk, hogy azok egyre többet hivatkoznak az EJEB gyakorlatára, ami inkább elvi szintű utalásnak tűnik a határozatban, mintsem tényleges hivatkozásnak, tekintettel arra, hogy leggyakrabban a „figyelemmel az EJEB és a Legfelsőbb Bíróság, majd a Kúria joggyakorlatára” szófordulat szerepel ezekben az ítéletekben. ${ }^{59}$ Elenyésző mértékben azonban tényleges hivatkozási alapul is szolgálnak az EJEE cikkei és az EJEB joggyakorlata a ma-

54 SzEMESI Sándor: Sok (jó) ember kis helyen? A magyar fegyintézetek zsúfoltságával kapcsolatos kérdések az Emberi Jogok Európai Bíróságának gyakorlatában. Büntetőjogi Szemle, 2014/2, 88. $3 \mathrm{~m}^{2}$ cellaméret alatt biztosra vehetö az állam elmarasztalása, míg 3 és $4 \mathrm{~m}^{2}$ között pedig az ügy összes körülményét figyelembe véve dönt az EJEB az állam elmarasztalásáról [a továbbiakban: SzEMEsI (2014)].

55 Bővebben lásd Szemesı Sándor: Repetitive Cases before the Strasbourg Court: The Pilot Judgment Procedure at the European Court of Human Rights. In: Láncos Petra Lea-Varga Réka-Molnár Tamás-Szabó Marcel (eds.): Hungarian Yearbook of International Law and European Law 2014. Eleven Publishing, The Hague, 2015, 243-258, illetve SzemEsı Sándor: Az emberi jogok európai örének új fegyvere: a pilot judgment eljárás a strasbourgi bíróság gyakorlatában. Jog-Állam-Politika, 2013/4, 47-63.

56 SzEMESI Sándor: Egy lehetséges válasz a szisztematikus jogsértésekre: A pilot judgment eljárás az Emberi Jogok Európai Bíróságának a gyakorlatában. In: Stipta István (szerk.): Collegium Doctorum Konferencia. Bíbor Kiadó, Miskolc, 2012, 2-4.

57 Torreggiani és mások kontra Olaszország ügy, 2013. január 8-i ítélet (ügyszám: 43517/09, 35315/10, 37818/10, 46882/09, 55400/09, 57875/09, 61535/09).

58 SZEMESI (2014): i. m., 86.

${ }^{59}$ Györi İtélőtábla, Bf.99/2013/17. 
gyar bíróságok számára, mint például a Fejér Megyei Bíróság 25.P.22.432/2008/61. számú határozata esetében, melyben az EJEE 6. cikkének elemzéséhez a Bock kontra Németország esetet vette alapul a bíróság a döntésének meghozatala során. ${ }^{60}$ Mindezek ellenére megállapítható, hogy a magyar ítélkezési gyakorlatban elsődleges hivatkozási alapként az EJEE gyakorlatával szinte soha nem találkozunk, legfeljebb az ítélet indoklásában vagy elvi szinten láthatunk rá utalást. ${ }^{61}$

A magyar bíróságok így a fentebb ismertetett hivatkozások közül leginkább az összefoglaló és az igazoló érvek típusát alkalmazzák, tehát az „érdemi” hivatkozások fajtáit szinte teljes mértékben nélkülözik, amelynek indoka talán a bírói szervezet nemzetközi normák mindennapi alkalmazásától való idegenkedése.

Ezáltal azon kettősség alakult ki a hazai judikatúrában, hogy az Alkotmánybíróság nyitottságával szemben - amely az európai mérce és gondolkodás (EJEE szövegének és EJEB joggyakorlatának) átvételében nyilvánul meg - a magyar bírói kar távolságtartásának és zártságának lehetünk tanúi. Ebből következik, hogy a strasbourgi bíróság Magyarországon majdnem kizárólag csak az Alkotmánybíróságon keresztül gyakorol közvetett hatást a magyar jogrendszerre.

\section{Következtetések}

A kiválogatott esetek és a magyar joggyakorlat vizsgálata alapján kíséreltem meg az Emberi Jogok Európai Bírósága részéröl a magyar jogrendszerre kifejtett közvetlen és közvetett hatásoknak a - korántsem teljes - bemutatását. Az alábbi táblázat érzékelteti a 2014. évben Magyarországgal szemben hozott elmarasztaló döntések belső jogi következményeit (a tisztességes eljáráshoz való jogot tartalmazó 6. cikk megsértésének 24 esetét kivéve).

\begin{tabular}{|c|c|c|c|c|}
\hline Ügy & $\begin{array}{c}\text { EJEB-döntés } \\
\text { (kérelem száma) }\end{array}$ & $\begin{array}{l}\text { Belső jogi eljárás } \\
\text { (kizárólag } \\
\text { AB határozatok) } \\
\text { az EJEB-eljárást } \\
\text { megelőzően }\end{array}$ & Közvetlen hatás & Közvetett hatás \\
\hline $\begin{array}{l}\text { Ungváry és } \\
\text { Irodalom Kft. }\end{array}$ & $\begin{array}{l}\text { 10. cikk sérelme } \\
(64520 / 10)\end{array}$ & - & - & - \\
\hline Hunvald & $\begin{array}{l}\text { 5. cikk sérelme } \\
(68435 / 10)\end{array}$ & - & - & - \\
\hline Nagy Gábor & $\begin{array}{l}\text { 5. cikk sérelme } \\
(33592 / 11)\end{array}$ & - & - & - \\
\hline Gál & $\begin{array}{l}\text { 5. cikk sérelme } \\
(62631 / 11)\end{array}$ & - & - & - \\
\hline
\end{tabular}

60 Fejér Megyei Bíróság, 25.P.22.432/2008/61, Fövárosi Törvényszék 136.G.43.307/2014/7, Székesfehérvári Törvényszék 25.P. 21.867/2011/15.

61 Szalal: i. m., 17. 
Az Emberi Jogok Európai Bírósága által előidézett változások a magyar jogrendszerben

\begin{tabular}{|c|c|c|c|c|}
\hline Ügy & $\begin{array}{c}\text { EJEB-döntés } \\
\text { (kérelem száma) }\end{array}$ & $\begin{array}{c}\text { Belső jogi eljárás } \\
\text { (kizárólag } \\
\text { AB határozatok) } \\
\text { az EJEB-eljárást } \\
\text { megelözöen }\end{array}$ & Közvetlen hatás & Közvetett hatás \\
\hline $\begin{array}{c}\text { Magyar keresztény } \\
\text { mennonita egyház } \\
\text { és mások }\end{array}$ & $\begin{array}{c}\text { 9. cikk sérelme } \\
(70945 / 11)\end{array}$ & $\begin{array}{c}\text { 6/2013. (III. 1.) AB } \\
\text { határozat } \\
\text { 27/2014. (VII. 23.) } \\
\text { AB határozat }\end{array}$ & $\begin{array}{c}\text { az EJEB-döntés } \\
\text { elött megszületett } \\
\text { a módosítás } \\
2013 . \text { CXXXIII. }\end{array}$ & - \\
\hline Magyar László & $\begin{array}{c}\text { 3. cikk sérelme } \\
(73593 / 10)\end{array}$ & - & 2014. évi LXXII. & 3013/2015. (I. 27.) \\
AB végzés
\end{tabular}

A fenti táblázatból megállapítható, hogy elmarasztalás esetén a leggyakoribb, hogy kártérités megfizetésére kötelezik hazánkat, amely azonban további jogszabályváltozást nem idéz elő. Ennek indokaként többféle magyarázat adható, elsöként, hogy legtöbbször a 6 . cikk miatt kerül hazánk elmarasztalásra, amely leginkább a bíróságok leterheltségében keresendő, amelynek orvoslására az eljárásjog olyan mértékủ átstrukturálása jelentene megoldást, amelyre a magyar jogalkotó még nem áll készen (hosszabb távon viszont a jelenleg is zajló új polgári perrendtartás és büntetőeljárási törvény kodifikációja megoldást jelenthet). A második nagyobb csoport esetében az ügyek egyedi jogsértése $k^{62}$ formájában kerültek a strasbourgi bíróság elé, amely nem kívánja meg a magyar jogrendszer érdemi módosítását.

62 Idesorolható például: Matúz kontra Magyarország ügy, 2014. október 21-i ítélet (ügyszám: 73571/10), Császy kontra Magyarország ügy, 2014. október 21-i ítélet (ügyszám: 14447/11), Cavani kontra Magyaror- 
A harmadik csoportba azokat az eseteket lehet sorolni, amelyek a magyar jogrendszer rendszerszintǘ3 problémájából erednek. Ezen utóbbi típusnál azonban rendkívül kiszámíthatatlan, hogy mikor idéz elő változást a jogrendszerben, mivel politikai, jogi és társadalmi környezet mellett az elmarasztalás várható mértéke és a várható esetek száma is befolyásolja azt. Így ez az időintervallum néhol többéves folyamattá duzzad, néhol pedig még az EJEB-döntés meghozatala előtt orvoslásra kerül a hiba.

Összefoglalóan megállapítható, hogy a magyar jogrendszerre az EJEB közvetlen és egyúttal közvetett hatást is fokozatosan, egyre nagyobb mértékben fejt ki, amely időigényes folyamat, azonban ez a hatás gyakorlatilag nem vehető észre a magyar bírói gyakorlatban. Remélhetőleg belátható időn belül a döntések hatásai immáron a hazai bírósági ítéletekben is érezhetőek lesznek, hiszen ez szükséges ahhoz, hogy az Emberi Jogok Európai Bírósága ítéletei teljes mértékben érvényesülhessenek a magyar jogrendszerben.

\section{Abstract}

Indisputably, the European Court of Human Rights (ECtHR) has an effect on national legal systems. In this study I examine the type of this effect in the Hungarian legal system through the case law of the year 2014, and as an outcome, I would like to demonstrate that the ECtHR has both direct and indirect impacts on the national legislation in Hungary. As a result of the judgments' direct impact, changes are made in the national legislation, meanwhile the indirect impact can only be detected in the decisions of the Hungarian Constitutional Court or domestic courts. Obviously, the direct impact is the most significant and most noticeable, however, the significance of indirect impact has been gradually increasing in the recent period. Based on this idea, I would like to point out that both effects are present in the Hungarian legislation, and seem to show an increasing trend, although the judicial bodies mean an exception in this practice. Nonetheless, according to the European practice, the judicial bodies will most likely refer to the international norm and the case law of the ECHR in the near future.

szág ügy, 2014. október 28-i ítélet (ügyszám: 5493/13), Amuruba kontra Magyarország ügy, 2014. július 22-i ítélet (ügyszám: 8167/07).

63 Idesorolható például: Hunvald kontra Magyarország ügy, 2013. december 10-i ítélet (ügyszám: 68435/10), Nagy Gábor kontra Magyarország ügy, 2014. február 11-i ítélet (ügyszám: 33529/11), Gál kontra Magyarország ügy, 2014. március 11-i ítélet (ügyszám: 62631/11), Gajcsi kontra Magyarország ügy, 2014. szeptember 23-i ítélet (ügyszám: 62924/10). 